\title{
Exploration of Teaching Reform of Professional Introduction Course in Electronic Information Engineering
}

\author{
Faquan Yang \\ Electronic and Information Engineering \\ Foshan University \\ Foshan, China \\ Yafaquan.fosu@163.com \\ Yonghao Xiao \\ Electronic and Information Engineering \\ Foshan University \\ Foshan, China \\ Yonghao@163.com \\ Yuexia Zhou \\ Electronic and Information Engineering \\ Foshan University \\ Foshan, China \\ Yuexia.edn@163.com
}

\author{
Jianwen Chen \\ Electronic and Information Engineering \\ Foshan University \\ Foshan, China \\ Jianwen.edn@163.com \\ Lijun Feng \\ Electronic and Information Engineering \\ Foshan University \\ Foshan, China \\ Lijun.edn@163.com \\ Qingfeng Cai \\ Electronic and Information Engineering \\ Foshan University \\ Foshan, China \\ Qingfeng.edn@163.com
}

\begin{abstract}
This paper mainly discuss the reform and exploration in teaching contents, teaching methods and evaluation system of professional introduction course for the electronic information engineering around new personal training plan. It also highlights innovation ability, practical ability and ability to pass the entrance of postgraduate exam and competitiveness of employment. The practice presents our teaching reform of professional introduction course is successful.
\end{abstract}

Keywords-electronic information engineering; professional introduction; innovation and practical ability; postgraduate exam and employment

\section{INTRODUCTION}

Professional introduction course is a compulsory course in the major of electronic information engineering, and it is the main way to introduce the major of electronic information engineering. The teaching quality of professional introduction course directly affects students learning initiative, learning ways and learning effect. Therefore, it is of great significance to reform and explore of the electronic information engineering professional introduction course teaching.

While combining with the characteristics of electronic information engineering knowledge, the paper[1] introduces the purpose and the teaching content construction for the electronic information engineering professional introduction course. Meanwhile, it also illustrates the design and idea of the course construction, which can provide the basis and reference for further construction in wider-caliber ability, knowledge, innovative talents training system.

The paper [2] put forward the idea of combining the freshman education with the professional introduction course. For the mentality and characteristics of the freshmen, the professional identity should be appropriately desalted during the teaching process while teaching the professional introduce course based on the correct guidance in students' idea, study way, interest, and ability. Meanwhile, this paper also introduced the talent training program, the special characteristics of college (e.g. open system of college laboratory and college innovation activity), the plan of postgraduate entrance exams and employment, the use of regular educational management system.

The paper [3] introduced the reform and practice of professional introduction courses in teaching mode, teaching content, teaching means, evaluation system and student feedback.

As our university is built as the high-level university of science and engineering in Guangdong province and "firstclass" students are firstly recruited in the electronic information engineering major, this paper discussed the reform of the original teaching method, teaching content, teaching way and evaluation system in the professional introduce course. , under the construction of high level polytechnic university in Guangdong Province. Compared with the original teaching ways of professional introduction for the 
"Second-class" students, undergraduate, innovation practice ability, professional learning interest and enthusiasm for postgraduate entrance examination can be improved.

\section{KEY PROBLEMS IN CURRICULUM REFORM OF PROFESSIONAL INTRODUCTION COURSE}

Since Foshan university is established as high-level university of science and engineering in 2015, "First class" students begin to be recruited. Because of the recruitment of "first class" students, the university not only takes action in the massive investment and construction in the experimental facility, but also rewriting talents training plan and the teaching programme of each course.

Therefore, course of professional introductory is no exception, and course of professional introductory should also be reformed in order to improve students' innovation and practice ability, postgraduate entrance examination and employment competitiveness.

In terms of Innovation and practical ability training, since the enrollment of "First class" students has a high starting point, the expectation of students' innovation and practice ability is also increased. Therefore, it is necessary to follow up the professional introduction course in innovation ability content training and guidance.

Similarly, when it comes to the postgraduate entrance exam, because "First class" enrolled students, the scores of cultural courses have been greatly improved. The proportion of students planning to take part in the postgraduate entrance examination will also increase substantially. Therefore, in the course of professional introduction, the content of postgraduate entrance examination guidance also needs to be added and enriched accordingly

\section{THE CONTENT RELATING TO THE REFORM OF INTRODUCTORY} COURSES

First of all, the purpose of setting the professional introduction is promoting students to know the major of electronic information engineering. More specifically, the students should know which courses they will learn, what characteristics these courses have, how to learn, and what kinds of studying way they can use.

Secondly, through setting up the professional introduction courses, it can introduce the training objectives of electronic information engineering professional, the requirements of comprehensive quality training and the structure system of electronic information engineering professional(including public courses, professional basic courses, compulsory courses for professional courses, professional restriction courses, professional optional courses),the professional curriculum design for the major of electronic information engineering and relative personal training program[4].

Thirdly, through comparing studying and living characteristics between college and high school, the students can be inspired to notice the improvement of studying ways.

Now, in order to improve innovative practice ability, the ability to pass postgraduate entrance examination and the competitiveness of employment for the "first-class" students, we nowadays add some teaching contents about extracurricular innovative practical courses based on the regular content.

For instance, we will encourage students to take part in academic forum, various science competition (e.g. National collegiate electronic design competition, Guangdong electronic design competition, electronic technology talents professional skills competition, national collegiate challenge cup and knowledge contest). Meanwhile, we plunge students to participate in collegiate innovation Entrepreneurship and all kinds of grade examination (e.g. CET, computer rank examination, software examination and so on). We also encourage students to declare patent and issue the paper.

Then, during the teaching process of professional introduction course, we use the regular time to introduce the basic knowledge of electronic information engineering including simple electronic circuit principle, electronic component detection, and electronic circuit drawing design principle, which can cultivate students' learning interest, increase the willingness of joining electronic association and lay a solid foundation for the professional practice skills[5].

In addition, for the assessment and evaluation of professional introduction courses, we not only evaluate the students' peacetime learning performance, final report professional introduction course, but also assess the performance in electron device circuit installation competition.

Finally, in order to answer the questions and encourage some new students who are willing to take part in the postgraduate examination after graduation, we also make special time to introduce the course about the postgraduate entrance exam, the relative requirements, and other knowledge about the preparation[6].

\section{THE REFORM IMPLEMENTATION EFFECT OF PROFESSIONAL INTRODUCTION COURSE.}

According to the above reform, the introductory course of electronic information engineering has been established for two years since 2016, and the recent effect has been as follows.

- Student satisfaction is high, after the course is opened, the students reflect that the blankness of entering the school was gradually resolved in the lecture. Some students who optionally apply for electronic information engineering without understand have the belief and expectation in learning this major and future prospect for employment.

- It can actively promote students' enthusiasm for innovation. During the teaching process of this course, we will arrange the fixed time to provide the education for students' innovation practical activity. From 2016 to 2017, more than $30 \%$ of freshmen enrolled in the electronic design association for two consecutive years. They regularly participated in the training activities of electronic basic knowledge and practical design ability. Compared with the students of 2014 and 2015, the students who participated in the electronic association were shown in TABLE I 
TABLE I. THE STUDENTS WHO PARTICIPATED IN THE ELECTRONIC ASSOCIATION

\begin{tabular}{|c|c|c|}
\hline $\begin{array}{c}\text { The number } \\
\text { and proportion }\end{array}$ & $\begin{array}{c}\text { The number of } \\
\text { students } \\
\text { participating in the } \\
\text { electronic society }\end{array}$ & Proportion \\
\hline 2014 & 12 & $15 \%$ \\
\hline 2015 & 13 & $16 \%$ \\
\hline 2016 & 40 & $29.6 \%$ \\
\hline 2017 & 70 & $30 \%$ \\
\hline
\end{tabular}

- Compared with other professional grade, students' learning motivation, learning achievement, etc has obviously improved, the number of students who have the aspiration in achieving the entrance postgraduate examination and take part in the electronic competition has an significant increase.

Compared with students in 2014 and 2015, the statistics of course performance, attendance and postgraduate entrance examination aspirations are shown in TABLE II

TABLE II. THE ST ATISTICS OF COURSE PERFORMANCE, ATTENDANCE AND POST GRADUATE ENTRANCE EXAMINATION ASPIRATIONS

\begin{tabular}{|c|c|c|c|}
\hline Groportion & $\begin{array}{c}\text { The } \\
\text { percentage } \\
\text { of people } \\
\text { who fail the } \\
\text { course }\end{array}$ & $\begin{array}{c}\text { The } \\
\text { proportion } \\
\text { of } \\
\text { absentees }\end{array}$ & $\begin{array}{c}\text { The wish } \\
\text { proportion } \\
\text { of } \\
\text { postgraduate } \\
\text { entrance } \\
\text { examination }\end{array}$ \\
\hline 2014 & $10 \%$ & $8 \%$ & $5 \%$ \\
\hline 2015 & $8 \%$ & $7.5 \%$ & $7.5 \%$ \\
\hline 2016 & $3.5 \%$ & $3 \%$ & $20 \%$ \\
\hline 2017 & $3 \%$ & $3 \%$ & $22 \%$ \\
\hline
\end{tabular}

\section{CONCLUSION}

Under the precondition of high level university construction, the teaching reform of this professional introductory course has obtained the high effect, and this course plays an important role in the professional training system. On the one hand, it makes the students understand more about the major, has high self-understanding, can set the plan for future. On the other hand, it makes students have a new understanding about the cultivation and value of innovation practice ability, postgraduate entrance examination and employment competitiveness. Therefore, the reform of this course is of great significance to the cultivation of electronic information engineering talents, the reform and exploration of the curriculum teaching system.

\section{ACKNOWLEDGMENT}

The authors wish to thank my classmates and friends in our laboratory in X'idan University such as Dr. Zhongxian PAN, Xinyin XIANG, Ganchao LIU, Dr. Jie Zheng et al. This work was supported in part by a grant from my work affiliation: school of electronic information engineering, Foshan University. In this paper, the research was sponsored by the professional comprehensive reform project of electronic information engineering of Foshan University.

\section{REFERENCES}

[1] J. Wang, Y.U. Fei, R.Song, "Teaching Introduction to Electronic Information Engineering Program: Course Development and Practice”. Journal of Shenzhen Polytechnic, vol(6). 32, pp. 212-216, June 2015.

[2] J.Li, L.Yuan, X.He, et al, "Talking About Professional Introduction Course of Energy and Power Engineering”. Science \& Technology Information, vol. 51(3), pp. 82-86, March 2015.

[3] R.J.Bland, R.A.Cobley, "Introduction of Electronic Design to An Engineering Science Core Course”. International Journal of Electrical Engineering Education, vol. 22(4), pp.293-298, April 2018.

[4] B.Zhu, X.J.Shi, "On Teaching Reform of Introduction to Civil Engineering”. Education Teaching Forum, vol. 30(8), pp.43-48, August 2018.

[5] Y.Liu, J.H.Hou, "Reforming about Introduction Course of Electric Information Majors”. Journal of Electrical \& Electronic Education, vol. 72(12), pp.20-24, December 2016.

[6] Y.Zhu, J.Zhang, “Teaching Reform and Practice of 'Numerical Control Technology' Course for Electrical Engineering Majors”. Journal of Changzhou Institute of Technology, vol. 52(8), pp.26-30, August 2016. 